\title{
ENTRE MÃOS ENRUGADAS, UMA VIAGEM AO PIAUÍ E NOVENTA E CINCO ANOS DE HISTÓRIA
}

\author{
Jéssica da Silva Rodrigues Cecim ${ }^{(a)}$
}

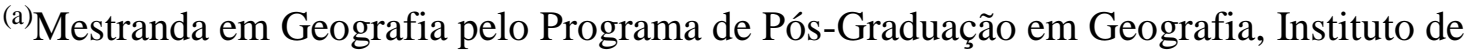
Geociências, Universidade Estadual de Campinas (UNICAMP). E-mail: jcecim@ gmail.com

Na noite da terça-feira que antecedeu o início do Simpósio Brasileiro de Geografia Física Aplicada, realizado na Unicamp nos últimos dias de junho e início de julho de 2017, recebi uma mensagem do meu orientador, coordenador da equipe de receptivo, em que pedia para que eu acompanhasse, durante o dia seguinte, uma professora em sua viagem relativamente curta em direção ao evento no qual ela seria homenageada. Essa era a possibilidade de estar com uma professora com muita experiência - mais especificamente noventa e cinco anos de experiência(s) -, que dentre outras viagens, já havia se embrenhado com uma amiga pela Amazônia em busca de seus estudos biogeográficos.

O primeiro momento em que me peguei pensando sobre os encaminhamentos que deveria tomar nessa vivência com a tal professora foi quando, estranhamente, não pegamos trânsito algum na cidade de São Paulo e chegamos ao seu apartamento cerca de quarentas minutos antes do combinado. Resolvi ligar e avisar que havia chegado antes e que, caso ela achasse melhor, poderia descer do apartamento para que fôssemos um pouco mais cedo para o evento. Acontece que a comunicação foi quase impossível, porque ela parecia não entender o que eu estava dizendo. Eu dizia "professora, já chegamos, se a senhora quiser descer agora podemos ir para o evento neste minuto", ao que ela respondia: “13h! 13h!”. Eu dizia: “tudo bem, professora, combinamos às $13 \mathrm{~h}$, mas como já estamos aqui, se a senhora quiser descer tudo bem, caso não queria, está tudo bem também" e ela mais uma vez "13h! 13h! 13h embaixo na portaria!".

Pensando agora, ainda mais depois de passar quase um dia inteiro com ela, percebo que talvez estivesse ela achando que era eu quem não estava entendendo nada dessa conversa e provavelmente resolveu falar apenas o mínimo para que eu não me confundisse ainda mais e por isso ficava repetindo " $13 \mathrm{~h}, 13 \mathrm{~h}, 13 \mathrm{~h} . .$. ".

Antes de continuar contando essa história, queria apenas fazer a observação de que, no dia anterior, havia pesquisado mais detalhadamente sobre sua vida e sua trajetória, assistido a entrevistas, procurado fotos etc. Fiquei receosa de não ser capaz de desenvolver uma conversa 
mínima com a professora, devido ao meu conhecimento defasado em relação à sua área de pesquisa e atividades desenvolvidas ao longo da vida. Passei a noite toda pensando que a nossa convivência no carro e a nossa conversa fluiria com dificuldade e que eu pareceria tola aos seus olhos.

Pois bem, acontece que o que achei que seria uma viagem sobre cursos de graduação, pesquisas e siglas de instituições por onde ela havia passado, virou, na realidade, a história de uma vida e, mais do que isso, uma história sobre como se viver a vida.

A conversa começou assim que entramos no carro, talvez até um pouco antes, enquanto ela abria a porta do prédio e mostrava a bolsa com os seus livros que deveriam ser levados para serem vendidos no evento. Ao olhá-la, pensava em minha avó, só que no lugar de livros de receita ou sobre sua religião, os livros eram sobre temas e conceitos biogeográficos.

Ao entrarmos no carro e colocarmos o cinto de segurança, ela pegou um colar de pedras azuis e me mostrou. $\mathrm{O}$ modo de pegar o colar era tão peculiar àquele tipo de mãos, àquela velocidade de movimentos; um tempo mais lento, menos ansioso, mais cuidadoso, tal qual o tempo e o modo como a minha avó raspa a vasilha de bolo enquanto despeja a massa na forma, ou como a avó de um amigo escolhia a chave do portão entre todo o molho que ela carregava no pescoço. Sorri e aguardei para ver o que ela faria com o colar; o retirou do saquinho, me mostrou e falou “bonito, né?”, respondi que sim, ainda muito receosa. Pediu ajuda para colocá-lo e enquanto eu o fazia e pensava "meu deus, como esse carro balança, tomara que eu não a machuque, tomara que consiga fechar o colar, porque esse fecho é difícil de manusear" ela começou a me contar a história do colar. Contou sobre uma viagem ao Piauí, ao Parque Nacional da Serra da Capivara, sobre os conflitos de terra na região e sobre pessoa responsável pelo Parque, até onde o avião ia na época, como eram as estradas... Enfim, tantas coisas! Tantos detalhes, nomes, lugares, especificidades do cotidiano que, no correr da vida, quando já não mais fazem parte da rotina, muitas vezes já não fazem mais parte da nossa memória também. Mas da dela faziam.

Uma história era ligada na outra. Ela sorria, ficava séria, contava um evento e esperava uma reação com os olhos de quem conta uma história muito incrível para uma criança e tem certeza de que vai causar surpresa. E causava! Eu era a criança e gostava de assim o ser. Apoiava meus cotovelos em meus joelhos e buscava atentamente por suas palavras. Às vezes o barulho do vento ou de um caminhão que passava não me permitia entender o que ela dizia e eu tinha medo de que ela achasse que eu não estava prestando atenção ou algo do tipo e então eu tomava coragem para interrompê-la e perguntar "desculpe, o que senhora disse?". 
Fomos a viagem inteira assim. Ela falava, eu ouvia, eu perguntava e nem sempre obtinha respostas. Foi uma hora e meia de histórias entre São Paulo e Campinas e enquanto o tempo passava eu percebia que nenhuma pesquisa biográfica que eu havia feito se comparava com ouvir diretamente dela o que havia sido vivido; percebi que a narrativa da vida pela voz, pelas entonações, os gestos e as emoções de quem viveu, pesquisa alguma na internet seria capaz de traduzir.

Quando chegamos ao evento, para mim já não era mais "a professora", era "a pessoa", que também era a professora, a pesquisadora, a aventureira que havia vivido tanta coisa e que se lembrava com muita lucidez de cada experiência vivenciada. Por um segundo invejei a memória, a coragem e as tomadas de decisão dela. Depois entendi que a admirava e que deveria tirar daquela experiência o que ela poderia me ensinar, além de pensar nas diversas possibilidades de sentido que cabiam à minha vida. E cabiam tantas significações...

Ao descermos do carro, fui deslocada novamente para o mundo no qual a roupa de professora, de pesquisadora e de profissional eram as principais roupas a serem vestidas. Percebi que não tinha dimensão do quanto aquela pessoa era admirada por aqueles que acompanhavam sua vida há mais tempo do que eu. A cada passo, ela era interpelada por uma pessoa. A cada livro tirado da bolsa e colocado em cima da mesa, eram mais pessoas que queriam um autógrafo. Alguns se demoravam mais tempo, perdidos assim como eu nas histórias, nas memórias e nas reticências do seu ato de contar. Sorri e esperei seu tempo, esperei os autógrafos e as conversas.

Fiquei pensando na pessoa que havia, juntamente com um grupo de geógrafos, explorado o lugar onde atualmente está erguida a capital federal. Quais seriam as paisagens daquele tempo? Será que essas pessoas têm em suas mentes as ressignificações pelas quais este espaço passaria? Ela me disse que, certa vez, ao dar uma palestra na UnB, em 1973, ficava se perguntando se o palco onde se encontrava agora teria sido erguido no mesmo lugar onde havia acampado em 1947, durante as expedições. Ficamos ambas imersas por um tempo em nossas reflexões acerca dessa contingência.

Durante o caminho de volta, apesar do cansaço - aparentemente mais meu do que dela -, pensava em uma série de perguntas que gostaria de fazer, mas antes que pudesse colocá-las em palavras, lá estava ela novamente com suas narrativas, suas impressões acerca do evento, seus sorrisos e suas expressões misteriosas de quem conta parte da história e espera que lhe perguntem o desfecho. 
Ao deixá-la em casa e pegar mais livros, já que os que haviam sido levados mais cedo tinham sido todos vendidos, pensava em quantas vezes desvinculamos a imagem da figura pública da pessoa. Quantas coisas mais não aprenderíamos e construiríamos sentidos se enxergássemos as pessoas enquanto mais complexas do que nossas buscas biográficas nos livros e pela internet fazem parecer? Naquele dia, novos modos de viver e ver a vida me foram ensinados; entre mãos enrugadas, uma viagem ao Piauí e noventa e cinco anos de história.

Um mês depois, essa senhora, a professora Dora Romariz, foi chamada para um outro plano, para construir outras histórias ou inundar a eternidade com as suas histórias incríveis. Saudades já! 